\title{
PENGARUH PIJAT PUNGGUNG TERHADAP TINGKAT KECEMASAN DAN KENYAMANAN PASIEN ANGINA PEKTORIS STABIL SEBELUM TINDAKAN ANGIOGRAFI KORONER
}

\author{
Eddy Rosfiati ${ }^{1,2^{*}}$, Elly Nurachmah $^{3}$, Yulia $^{3}$ \\ 1. Sekolah Tinggi Ilmu Kesehatan Jayakarta, Pondok Karya Pembangunan DKI, Jakarta 13730, Indonesia \\ 2. Program Studi Magister, Fakultas Ilmu Keperawatan Universitas Indonesia, Depok 16424, Indonesia \\ 3. Fakultas Ilmu Keperawatan, Universitas Indonesia, Depok 16424, Indonesia \\ *E-mail: rosfiati@gmail.com
}

\begin{abstract}
Abstrak
Menghadapi tindakan diagnostik coronary angiography dan kemungkinan diintervensi lanjut dengan PCI, pasien APS sering cemas, merasa tidak nyaman karena stres. Cemas dan tidak nyaman sebagai respon fisiologis dan psikologis tubuh, terlihat juga pada perubahan tekanan darah, nadi, respirasi, dan suhu. Penelitian ini untuk mengetahui pengaruh pijat punggung terhadap tingkat kecemasan dan kenyamanan serta dampaknya pada tekanan darah, nadi, respirasi, dan suhu sebelum tindakan coronary angiography. Penelitian ini menggunakan desain equivalent pretest-posttest with control group quasi experiment, dengan pemilihan sampel probability simple random sampling sejumlah 30 responden. Data kecemasan dan kenyamanan dikumpulkan menggunakan kuesioner berskala 0-10, pengukuran tekanan darah dan jumlah denyut nadi menggunakan tensimeter digital dan suhu menggunakan termometer digital dengan baterai. Hasil penelitian menunjukkan perbedaan sesudah pijat punggung pada tingkat kecemasan, tingkat kenyamanan, tekanan darah diastolik, nadi, respirasi, dan suhu ( $\mathrm{p}=0,002 ; 0,0001 ; 0,016 ; 0,0001 ; 0,005 ; 0,052)$. Pijat punggung dapat digunakan untuk mengurangi stres psikologis (kecemasan) dan meningkatkan kenyamanan pasien sebelum tindakan coronary angiography. Rekomendasi ditujukan kepada manajemen ruangan untuk mengaplikasikan pijat punggung sebagai bagian dari SPO angiography.
\end{abstract}

Kata kunci: coronary angiography, pasien APS, pijat punggung, respons fisiologis-psikologis, stres

\begin{abstract}
The Effects of Back Rub on Anxiety and Comfort Level of Patients with Stable Angina Pectoris Before Coronary Angiography Procedure at Cardiac and Cardiovascular. Dealing with coronary angiography diagnostic procedures and the possibility of being intervene with PCI, SAP patients are often anxious, feel uncomfortable due to stress. Anxiety and discomfort are physiological and psychological response, which can be noticed on the change in blood pressure status, pulse, respiration and body temperature. This research was conducted with the main objective to identify the effect of back rub on the level of patient's anxiety and comfort before coronary angiography procedure. Design used in this research was an equivalent pretest-posttest with control group quasi experiment. Research was conducted using probability simple random sampling; with 30 respondents participated. A questionnaire was used for data collecting of anxiety level with 0-10 scale, digital sphygmomanometer was used for measuring blood pressure and pulse rate, and digital battery powered thermometer was used for measuring body temperature. The results showed differences after back-rub were found in anxiety, comfort, diastolic BP, pulse, respiration, and temperature ( $p=0,002$; 0,0001; 0,016; 0,0001; 0,005; 0,052). Based on the findings, it can be concluded that back-rub can be applied to reduce patient's psychological stress (anxiety) and increase comfort before coronary angiography procedure. A recommendation is directed to the management of the ward to apply back-rub as a part of SOP of Angiography Procedure.
\end{abstract}

Keywords: back-rub, coronary angiography, physical response, psychological response, SAP patients', stress

\section{Pendahuluan}

Pasien dengan angina pektoris stabil (APS) yang menghadapi tindakan diagnostik coronary angiography dan kemungkinan diintervensi lanjut dengan percutaneous coronary interventions $(\mathrm{PCI})$, sering cemas dan merasa tidak nyaman karena stres. Cemas dan tidak nyaman sebagai respon fisiologis dan psikologis tubuh, terlihat dengan perubahan tekanan darah, nadi, respirasi, dan suhu. 
Respon pasien berbentuk respon psikologis yang beragam termasuk timbulnya kecemasan, ketakutan, ketegangan bahkan depresi. Pasien yang dilakukan tindakan kateterisasi jantung dengan coronary angiography dan PCI, tetap mengalami kecemasan walaupun sudah dipersiapkan dengan baik termasuk pemberian penjelasan prosedur dan segala risiko yang dapat terjadi serta informed consent yang ditandatangani pasien (Eran, Erdmann, \& Er, 2010).

Back $r u b$ atau pijat punggung juga dapat diberikan kepada pasien untuk meningkatkan relaksasi sebelum pasien menjalani tindakan coronary angiography (McNamara, Burnham, Smith, \& Carrol, 2003). Pijat punggung merupakan salah satu tindakan alternatif dan terapi komplementer seperti terapi musik, relaksasi, guided imagery, reflexiology, herbal medicine, hypnotis, terapi sentuhan yang digunakan untuk mengurangi nyeri, cemas, takikardia, dan hipertensi pada pasien beberapa tahun terakhir ini. Pijat punggung bertujuan untuk membantu pengobatan sistem saraf dan kardiovaskular secara efektif menimbulkan rasa aman, rileks, dan rasa nyaman (Hajbaghery, Abasi, \& Behestabad, 2012). Di Indonesia, pijat punggung dilakukan ketika perawat memandikan pasien dengan tirah baring untuk memberikan rasa nyaman dan belum ada penelitian khusus tentang manfaat pijat punggung ini dan belum ada data yang menunjukkan hasil dari pijat punggung tersebut.

Pertanyaan penelitian yang akan dijawab dalam penelitian ini adalah bagaimana pengaruh pijat punggung terhadap tingkat kecemasan dan tingkat kenyamanan pasien sebelum tindakan coronary angiography. Tujuan umum penelitian ini adalah mengidentifikasi pengaruh pijat punggung terhadap tingkat kecemasan dan tingkat kenyamanan pasien angina pektoris stabil sebelum tindakan coronary angiography di sebuah rumah sakit di Jakarta.

\section{Metode}

Desain penelitian ini menggunakan satu kelompok intervensi dan satu kelompok kontrol, yaitu tindakan yang dilaksanakan pada satu kelompok perlakuan dan satu kelompok kontrol sebagai pembanding. Sebelum dan sesudah perlakuan pada kelompok dilakukan pengukuran awal (pretest) dan posttest termasuk pengukuran tekanan darah (TD), nadi, respirasi, dan suhu. Pengambilan sampel dengan menggunakan simple random sampling (Dharma, 2011) dan didapatkan sebanyak 30 responden. Variabel penelitian ini yaitu pemberian intervensi pijat punggung (variabel bebas), tingkat kecemasan dan tingkat kenyamanan (variabel terikat), serta usia, jenis kelamin, pendidikan, dan pekerjaan (variabel perancu).

Instrumen pengambilan data yang digunakan adalah kuesioner, persepsi tingkat kecemasan sebelum dan sesudah intervensi yang dimodifikasi peneliti dari gugup (nervous), khawatir (worried), dan tegang (tense)/NEWTEN (Kari, 2009). Tingkat kecemasan diukur dengan rentang skala 0-10, untuk mengukur: gugup (nervous), khawatir (worried), dan tegang (tense). Angka 0 mewakili pengertian bahwa tidak ada; $1-3=$ ringan; $4-6=$ sedang; $7-8=$ berat dan $9-10=$ sangat berat. Persepsi tingkat kenyamanan menggunakan skala Verbal Rating Scale Questioner dari Kolcaba yang dimodifikasi peneliti (Dowd, et al. 2007). Instrumen ini dipilih untuk mengukur Kenyamanan yang dirasakan responden dengan rentang skala $0-10$. Angka 0 mewakili pengertian bahwa tidak nyaman; $1-3=$ sedikit nyaman; $4-6=$ nyaman sedang; $7-8=$ nyaman, dan $9-10=$ sangat berat. Kuesioner B merupakan lembar observasi, diisi oleh observer sesuai dengan hasil pengukuran dan pengamatan secara langsung untuk mengidentifikasi tanda-tanda fisiologis (tekanan darah, nadi, respirasi, dan suhu).

Analisis data menggunakan uji statistik independent $t$ test untuk menguji hipotesis komparatif rerata. Satu sampel dalam pengukuran berarti sampel tersebut berpasangan, yaitu model beforeafter yang dibandingkan dengan kelompok kontrol. Satu sampel diberi perlakuan 1 kali (Sugiono, 2010). Nilai confidence interval (CI) yang digunakan adalah $95 \%$ dengan tingkat kemaknaan $5 \%(\alpha=0,05)$. Pada penelitian ini 
dilakukan juga uji homogenitas pada faktor konfonding pada kedua kelompok intervensi dan kelompok kontrol. Model statistik yang digunakan yaitu uji homogenitas dengan ChiSquare, Kolmogorof-Smirnov test, uji independent$t$, korelasi, dan regresi linear sederhana. Uji homogenitas responden penelitian berdasarkan usia, jenis kelamin, pendidikan, dan pekerjaan memiliki kesetaraan atau tidak ada perbedaan yang signifikan pada kelompok intervensi dan kelompok kontrol yang dibuktikan dari hasil uji statistik keempat variabel tersebut memiliki nilai $\mathrm{p}>\alpha(0.05)$.

\section{Hasil}

Hasil penelitian pada Tabel 1 menunjukkan bahwa rerata usia responden pada kelompok intervensi $(\mathrm{SD}=9,3)$ dan kelompok kontrol $(\mathrm{SD}=9,0)$ tidak berbeda yaitu 58 tahun $(95 \%$ CI). Usia minimum kelompok intervensi 43 tahun dan kelompok kontrol 46 tahun dengan usia maksimum yang sama yaitu 73 tahun. Tabel 2 menerangkan tentang jenis kelamin, pendidikan responden dan pekerjaan yang berisikan bahwa responden berjenis kelamin laki-laki yang paling banyak yaitu 83,3\% (25 orang) yang terdiri dari $43,3 \%$ (13 orang) di kelompok intervensi dan 40\% (12 orang) di kelompok kontrol. Proporsi responden berjenis kelamin perempuan sejumlah $16,6 \%$ (5 orang) yang terdiri dari $6,6 \%$ (2 orang) di kelompok intervensi dan 10\% (3 orang) di kelompok kontrol.

Karakteristik responden berdasarkan pendidikan perguruan tinggi yang paling banyak yaitu $70 \%$ (21 orang), terdiri dari $46,6 \%$ (14 orang) di kelompok intervensi dan 23,3\% (7 orang) di kelompok kontrol, responden berpendidikan SLTA berjumlah $26,7 \%$ (8 orang) yang terdiri dari 3,3\% (1 orang) di kelompok intervensi dan $23,3 \%$ (7 orang) di kelompok kontrol, dan hanya $3,3 \%$ responden atau 1 orang responden dengan pendidikan SLTP. Berdasarkan pekerjaan responden dengan pekerjaan sebagai karyawan swasta adalah responden yang paling banyak yaitu 46,7\% (14 orang) dengan jumlah yang sama pada kelompok intervensi dan kelompok kontrol yaitu masing-masing $23,3 \%$.

Tabel 1. Karaktersitik Responden Berdasarkan Usia (tahun)

\begin{tabular}{lcccccc}
\hline \multicolumn{1}{c}{ Variabel Usia } & Mean & Median & SD & Minimum & Maksimum & n \\
\hline Kelompok Intervensi & 58 & 60 & 9.3 & 43 & 73 & 15 \\
Kelompok Kontrol & 58 & 55 & 9.0 & 46 & 73 & 15 \\
\hline
\end{tabular}

Tabel 2. Karakteristik Responden Berdasarkan Jenis Kelamin, Pendidikan dan Pekerjaan

\begin{tabular}{lcccc}
\hline \multicolumn{1}{c}{ Karakteristik } & Kelompok Intervensi & Kelompok Kontrol & N & Presentase (\%) \\
\hline \multicolumn{1}{c}{ Jenis Kelamin } & \multicolumn{2}{c}{} \\
\hline Laki-laki & 13 & 12 & 25 & 83,3 \\
Perempuan & 2 & 3 & 5 & 16,6 \\
$\quad$ Jumlah & 15 & 15 & 30 & 100 \\
\hline \multicolumn{1}{c}{ Pendidikan } & & & & \\
\hline SLTP & - & 1 & 1 & 3,3 \\
SLTA & 1 & 7 & 8 & 26,7 \\
PT $\quad 14$ & 7 & 21 & 70 \\
\multicolumn{1}{c}{ Jumlah } & 15 & 15 & 30 & 100 \\
\hline \multicolumn{1}{r}{ Pekerjaan } & & & & \\
\hline PNS & 3 & 5 & 8 & 26,7 \\
Swasta & 7 & 7 & 14 & 46,7 \\
Lain-lain & 5 & 3 & 8 & 26,7 \\
$\quad$ Jumlah & 15 & 15 & 30 & 100 \\
\hline
\end{tabular}


Responden dengan pekerjaan sebagai PNS dan pekerjaan lain termasuk pensiunan masing-masing berjumlah $26,7 \%$. Hasil penelitian pada Tabel 3 didapatkan bahwa rerata tingkat kecemasan responden sebelum pijat punggung terdapat perbedaan pada kelompok intervensi dan kelompok kontrol $(\mathrm{p}=0,048)$.

Hasil penelitian pada Table 4 didapatkan bahwa rerata tingkat kecemasan responden sesudah pijat punggung terdapat perbedaan yang signifikan pada kelompok intervensi dan kelompok kontrol $(p=0,002)$. Selain itu didapatkan (Tabel 5) juga hasil bahwa terdapat perbedaan yang signifikan pada tingkat kenyamanan setelah pijat punggung $(p=0,0001)$ Data tersebut menunjukkan ada pengaruh pijat punggung terhadap tingkat kecemasan dan tingkat kenyamanan pasien angina pektoris stabil sebelum tindakan coronary angiography $(\mathrm{n}=30)$. Tabel 6 menerangkan bahwa rerata tekanan darah sistolik responden sebelum pijat punggung tidak ada perbedaan yang signifikan $\mathrm{p}=0,112$ pada kelompok intervensi $=$ $153,53 \mathrm{mmHg}$, SD 20,184 mmHg, kelompok kontrol $=141,80 \mathrm{mmHg}$, SD 18,974 $\mathrm{mmHg}$.

Tabel 3. Karakteristik Responden Berdasarkan Pekerjaan

\begin{tabular}{lcccc}
\hline \multicolumn{1}{c}{ Pekerjaan } & Kelompok Intervensi & Kelompok Kontrol & N & Presentase (\%) \\
\hline PNS & 3 & 5 & 8 & 26,7 \\
Swasta & 7 & 7 & 14 & 46,7 \\
Lain-lain & 5 & 3 & 8 & 26,7 \\
$\quad$ Jumlah & 15 & 15 & 30 & 100 \\
\hline
\end{tabular}

Tabel 4. Tingkat Kecemasan Kelompok Intervensi dan Kontrol Sebelum dan Sesudah Pijat Punggung

\begin{tabular}{cccccc}
\hline Tingat Kecemasan & Mean & SD & SE & p* & n \\
\hline Sebelum Pijat Punggung & & & & & \\
\hline Kelompok Intervensi & 6,73 & 1,870 & 0,483 & 0,048 & 15 \\
$\quad$ Kelompok Kontrol & 5,53 & 1,246 & 0,322 & & \\
\hline \multicolumn{1}{c}{ Sesudah Pijat Punggung } & & & & & 15 \\
\hline Kelompok Intervensi & 3,67 & 1,676 & 0,433 & 0,002 & 15 \\
Kelompok Kontrol & 5,53 & 1,246 & 0,322 & & \\
\hline
\end{tabular}

$* \alpha=0,05$

Tabel 5. Tingkat Kenyamanan Kelompok Intervensi dan Kontrol Sebelum dan Sesudah Pijat Punggung

\begin{tabular}{lccccc}
\hline \multicolumn{1}{c}{ Tingkat Kenyamanan } & Mean & SD & SE & p* & n \\
\hline \multicolumn{1}{c}{ Sebelum Pijat Punggung } & & & & & \\
\hline Kelompok Intervensi & 5,07 & 1,163 & 0,300 & \multirow{2}{*}{0,454} & 15 \\
Kelompok Kontrol & 5,40 & 1,242 & 0,321 & & 15 \\
\hline \multicolumn{1}{c}{ Sesudah Pijat Punggung } & & & & & 15 \\
\hline Kelompok Intervensi & 7,53 & 0,834 & 0,125 & \multirow{2}{*}{0,0001} & 15 \\
Kelompok Kontrol & 5,60 & 1,242 & 0,321 & & \\
\hline
\end{tabular}

$* \alpha=0,05$ 
Tabel 6. Tekanan Darah Sistole dan Diastole Kelompok Intervensi dan Kontrol Sebelum dan Setelah Pijat Punggung

\begin{tabular}{|c|c|c|c|c|c|}
\hline Tekanan Darah Sistole & Mean & SD & SE & $\mathbf{p}^{*}$ & $\mathbf{n}$ \\
\hline \multicolumn{6}{|l|}{ Sebelum Pijat Punggung } \\
\hline Kelompok Intervensi & 153,53 & 20,184 & 5,212 & \multirow{2}{*}{0,112} & 15 \\
\hline Kelompok Kontrol & 141,80 & 18,974 & 4,899 & & 15 \\
\hline \multicolumn{6}{|l|}{ Sesudah Pijat Punggung } \\
\hline Kelompok Intervensi & 141,13 & 19,755 & 5,101 & \multirow{2}{*}{0,826} & 15 \\
\hline Kelompok Kontrol & 142,67 & 18,102 & 4,674 & & 15 \\
\hline \multicolumn{6}{|l|}{ Tekanan Darah Diastole } \\
\hline \multicolumn{6}{|l|}{ Sebelum Pijat Punggung } \\
\hline Kelompok Intervensi & 76,60 & 9,478 & 2,447 & \multirow{2}{*}{0,352} & 15 \\
\hline Kelompok Kontrol & 80,73 & 13,997 & 3,614 & & 15 \\
\hline \multicolumn{6}{|l|}{ Sesudah Pijat Punggung } \\
\hline Kelompok Intervensi & 68,80 & 8,082 & 2,087 & \multirow{2}{*}{0,016} & 15 \\
\hline Kelompok Kontrol & 78,87 & 12,867 & 3,322 & & 15 \\
\hline
\end{tabular}

${ }^{*} \alpha=0,05$

Pada Tabel 6 merangkan tentang tekanan darah sistolik dan diastolik responden sebelum dan sesudah pijat punggung. Rerata tekanan darah sistolik responden sesudah pijat punggung tidak ada perbedaan yang signifikan $\mathrm{p}=0,826$ pada kelompok intervensi $=141,13 \mathrm{mmHg}, \mathrm{SD}$ $19,755 \mathrm{mmHg}$, kelompok kontrol $=142,67$ $\mathrm{mmHg}$, SD 18,102 mmHg. Rerata tekanan darah diastole responden sebelum pijat punggung tidak ada perbedaan yang signifikan $\mathrm{p}=0,352(>$ dari $\alpha$ ), pada kelompok intervensi $=76,60 \mathrm{mmHg}$, SD 9,478 $\mathrm{mmHg}$, kelompok kontrol= 80,73 $\mathrm{mmHg}$, SD 13,997 mmHg. Rerata tekanan darah diastole responden sesudah pijat punggung ada perbedaan yang signifikan $\mathrm{p}=0,016(<$ dari $\alpha$ ), pada kelompok intervensi $=68,80 \mathrm{mmHg}$, SD $8,082 \mathrm{mmHg}$, kelompok kontrol $=78,87$ mmHg, SD 12,867 mmHg. Tabel 7 menerangkan tentang denyut nadi, respirasi dan suhu sebelum dan sesudah pijat punggung. Berdasarkan denyut nadi responden yaitu sebelum pijat punggung tidak ada perbedaan yang signifikan $\mathrm{p}=0,444$ (> dari $\alpha$ ) pada kelompok intervensi $=76,00 \mathrm{kali} /$ menit, SD 11,244 kali/ menit, pada kelompok kontrol $=79,07 \mathrm{kali} /$ menit, SD 10,347 kali/ menit. Sesudah pijat punggung ada perbedaan yang signifikan $\mathrm{p}=0,0001(<$ dari $\alpha)$, pada kelompok intervensi $=65,00 \mathrm{kali} / \mathrm{menit}, \mathrm{SD}$ 7,181 kali/ menit, pada kelompok kontrol= 81,47 kali/ menit dengan SD 9,841 kali/ menit. respirasi responden sebelum pijat punggung tidak ada perbedaan yang signifikan $\mathrm{p}=0,733$ $(>$ dari $\alpha$ ), pada kelompok intervensi $=20,13$ kali/menit, SD 2,532 kali/menit, pada kelompok kontrol $=19,87 \mathrm{kali} /$ menit, SD $1,598 \mathrm{kali} /$ menit. Respirasi responden sesudah pijat punggung terdapat perbedaan yang signifikan $\mathrm{p}=0,05(=\alpha)$, pada kelompok intervensi= 18,47 kali/menit, SD 1,125 kali/menit, pada kelompok kontrol= 19,87 kali/menit, SD 1,407 kali/menit. Suhu responden sebelum pijat punggung tidak ada perbedaan yang signifikan $\mathrm{p}=0,324(>$ dari $\alpha)$, pada 
Tabel 7. Denyut Nadi, Respirasi, Suhu Kelompok Intervensi dan Kontrol Sebelum dan Sesudah Pijat Punggung

\begin{tabular}{|c|c|c|c|c|c|}
\hline Denyut Nadi & Mean & SD & SE & $\mathbf{p}^{*}$ & $\mathbf{N}$ \\
\hline \multicolumn{6}{|c|}{ Sebelum Pijat Punggung } \\
\hline Kelompok Intervensi & 76,00 & 11,244 & 2,903 & \multirow{2}{*}{0,444} & 15 \\
\hline Kelompok Kontrol & 79,07 & 10,347 & 2,672 & & 15 \\
\hline \multicolumn{6}{|c|}{ Sesudah Pijat Punggung } \\
\hline Kelompok Intervensi & 65,00 & 7,181 & 1,854 & \multirow{2}{*}{0,0001} & 15 \\
\hline Kelompok Kontrol & 81,47 & 9,841 & 2,541 & & 15 \\
\hline Respirasi & Mean & SD & SE & $\mathbf{p}^{*}$ & $\mathbf{n}$ \\
\hline \multicolumn{6}{|c|}{ Sebelum Pijat Punggung } \\
\hline Kelompok Intervensi & 20,13 & 2,532 & 0,654 & \multirow{2}{*}{0,733} & 15 \\
\hline Kelompok Kontrol & 19,87 & 1,598 & 0,413 & & 15 \\
\hline \multicolumn{6}{|c|}{ Sesudah Pijat Punggung } \\
\hline Kelompok Intervensi & 18,47 & 1,125 & 0,291 & \multirow{2}{*}{0,05} & 15 \\
\hline Kelompok Kontrol & 19,87 & 1,407 & 0,363 & & 15 \\
\hline Suhu & Mean & SD & SE & $\mathbf{p}^{*}$ & $\mathbf{n}$ \\
\hline \multicolumn{6}{|c|}{ Sebelum Pijat Punggung } \\
\hline Kelompok Intervensi & 36,51 & 0,397 & 0,098 & \multirow{2}{*}{0,324} & 15 \\
\hline Kelompok Kontrol & 36,67 & 0,488 & 0,126 & & 15 \\
\hline \multicolumn{6}{|c|}{ Sesudah Pijat Punggung } \\
\hline Kelompok Intervensi & 36,33 & 0,362 & 0,093 & 0,052 & 15 \\
\hline Kelompok Kontrol & 36,67 & 0,523 & 0,135 & & 15 \\
\hline
\end{tabular}

kelompok intervensi $=36,51{ }^{\circ} \mathrm{C}, \mathrm{SD} 0,379{ }^{\circ} \mathrm{C}$, pada kelompok kontrol $=36,67^{\circ} \mathrm{C}, \mathrm{SD} 0,488^{\circ} \mathrm{C}$. Rerata suhu sesudah pijat punggung ada perbedaan yang signifikan $\mathrm{p}=0,052,(=\alpha)$, pada kelompok intervensi $=36,33{ }^{\circ} \mathrm{C}, \mathrm{SD} 0,362^{\circ} \mathrm{C}$, pada kelompok kontrol $=36,67^{\circ} \mathrm{C}, \mathrm{SD} 0,523^{\circ} \mathrm{C}$.

Hubungan antara tingkat kecemasaan dan tingkat kenyamanan diuji melalui uji korelasi dan regresi linear sederhana. Hasil analisis statistik dapat dikaji nilai-nilai dalam regresi linear yaitu koefisien determinasi, persamaan garis dan $\mathrm{p}$. Nilai koefisien determinasi dilihat pada nilai $\mathrm{R}^{2}$ (R Square) dalam tabel Model Summary yaitu 0,344, pada Confidence Interval $95 \%$ artinya persamaan garis regresi yang didapat menjelaskan 34,4\% variasi tingkat kenyamanan. Pada tabel Anova didapat nilai $\mathrm{p}($ kolom Sig) $=$ $0,001<$ dari $\alpha(0,05)$, sehingga disimpulkan bahwa regresi sederhana cocok dengan data yang ada. Dari hasil diatas didapat nilai konstan (a) sebesar 8,793 dan nilai $b=-0,484$. Maka rumusan model prediksi tingkat kenyamanan dari tingat kecemasan pasien setelah diberikan pijat punggung, dengan persamaan regresi sebagaimana persamaan (1) berikut:

$$
\mathrm{Y}=\mathrm{a}+\mathrm{bX}
$$

Tingkat kenyamanan setelah pijat punggung= $8,793+\{(-0,484)($ tingkat kecemasan $)\}$

\section{Pembahasan}

Penelitian mempunyai tujuan untuk mendapatkan gambaran tentang pengaruh pijat punggung terhadap tingkat kecemasan dan tingkat kenyamanan pasien sebelum tindakan coronary angiography. Usia dominan menurut Black dan Hawks (2009) yang mengalami penyakit jantung koroner adalah $>40$ tahun. Sesuai dengan faktor yang mempengaruhi respon individu terhadap stres, juga 
faktor usia rerata 50-60 tahun, pada populasi $<30$ tahun sampai usia $\geq 70$ tahun (Hinz, et al., 2011). Jenis kelamin, walaupun kedua jenis kelamin dapat sama-sama mengalami penyakit jantung koroner, laki-laki merupakan jenis kelamin yang berisiko tinggi mengalami penyakit jantung koroner pada usia lebih muda dan perempuan berisiko meningkat secara signifikan setelah menopause 2-3 kali dibandingkan dengan perempuan pada usia sama sebelum menopause (Black \& Hawks, 2009). Demikian pula faktor jenis kelamin terhadap tingkat kecemasan pasien sebelum tindakan coronary angiography, oleh Hinz, et al., (2011) dalam Anxiety and Depression in Cardiac Patients: Age Diffrences and Comparison with General Population, dikatakan bahwa kedua jenis kelamin mempunyai tingkat kecemasan yang setara.

Hasil penelitian karakteristik responden dengan pendidikan perguruan tinggi mendominasi diagnosis angina pektoris stabil memperlihatkan bahwa pendidikan juga merupakan salah satu faktor bahwa seseorang lebih memahami kondisi jantung sehingga melanjutkan pemeriksaan diagnosis ke tingkat coronary angiography. Pekerjaan responden yang datang untuk tindakan coronary angiography didapatkan yang paling banyak adalah swasta, baik di kelompok intervensi dan kelompok kontrol karena jaminan sosial kesehatan yang pasti mereka memiliki kemudahan untuk memutuskan melakukan tindakan ini, walaupun ini juga terjadi pada responden dengan pekerjaan Pegawai Negeri Sipil (PNS) ada jaminan tapi terlihat lebih sedikit yang melanjutkan untuk tindakan diagnostik coronary angiography.

Tingkat kecemasan sebelum intervensi pada kelompok intervensi dan kelompok kontrol memperlihatkan pada awalnya bahwa kelompok intervensi $(6,73)$ dan kelompok kontrol $(5,53)$ mempunyai tingkat kecemasan yang lebih tinggi dibandingkan dengan kelompok kontrol sebelum diberikan pijat punggung sebagai data dasar. Dari penelitian terdahulu ditemukan $51 \%$ dilaporkan mengalami stres secara klinis, cukup signifikan menggunakan alat ukur Distress
Thermometer (DT), 52\% pasien dilaporkan mengalami depresi dengan level tinggi, kegugupan atau mengalami keduanya yang diukur menggunakan alat ukur Edmonton Symptom Assessment Scale (ESAS). Penelitian tersebut dilakukan untuk menyelidiki hubungan faktor-faktor fisiologis dan psikologis menghadapi diagnosis kanker paru (Steinberg, et al., 2009). Menurut artikel medikal yang ditulis Kugler (2009) tentang Waiting for diagnostic, seseorang yang menunggu diagnostik mengalami respon stres, seperti marah (anger), tidak sabar, frustrasi dan ansietas, sedih bahkan depresi sebagai akibat reaksi fisiologis dan psikologis tubuh.

Tingkat kecemasan sesudah intervensi pada kelompok intervensi dan kelompok kontrol memperlihatkan bahwa tingkat kecemasan kelompok intervensi 3,67 menjadi berkurang secara signifikan dibandingkan dengan tingkat kecemasan kelompok kontrol $(5,53)$ yang menetap karena tidak diintervensi dengan pijat punggung walaupun pada awalnya kedua kelompok mempunyai tingkat kecemasan yang relatif sama tinggi sebelum intervensi $(p=0,002)$. Sesuai dengan penelitian terdahulu pijat punggung yaitu the effect of massage intervention on anxiety, comfort and physiological responses in patient with congestive heart failure (Liebert, 2012), massage therapy dapat meningkatkan saturasi oksigen secara signifikan, responden laki-laki lebih merasakan berkurangnya ansietas secara signifikan. Pada penelitian the effect of backmassage on the vital signs and anxiety level of elderly staying in a rest home, didapatkan antara lain ada penurunan tingkat kecemasan secara signifikan $(\mathrm{p}=0,001)$ setelah pijat punggung (Cinar, Eser, \& Khorshid, 2009). Berarti pijat punggung mampu memberikan ketenangan kepada pasien secara signifikan.

Tingkat kenyamanan sebelum intervensi pada kelompok intervensi dan kelompok kontrol memperlihatkan pada awalnya bahwa kelompok intervensi $(5,07)$ dan kelompok kontrol $(5,53)$ mempunyai tingkat kenyamanan yang relatif sama rendah dengan kelompok kontrol sebelum diberikan pijat punggung $(\mathrm{p}=0,454)$. Menurut 
Kolcaba (2010), rasa nyaman didapatkan bila tidak ada ancaman terhadap diri seseorang. Dalam kondisi menunggu tindakan seperti coronary angiography, dimana diagnosis ditentukan setelah tindakan dilakukan menjadi ancaman bagi pasien, hal ini yang membuat pasien tidak nyaman.

Tingkat kenyamanan sesudah intervensi pada kelompok intervensi dan kelompok kontrol. memperlihatkan bahwa tingkat kenyamanan kelompok intervensi $(7,53)$ menjadi meningkat secara signifikan dibandingkan dengan tingkat kenyamanan kelompok kontrol $(5,60)$ yang tidak diintervensi dengan pijat punggung walaupunpada awalnya kedua kelompok mempunyai tingkat kenyamanan yang relatif sama rendah sebelum intervensi $(p=0,0001)$. Sesuai dengan penelitian yang dilakukan oleh Chen, Liu, Yeh, Chiang, Fu, dan Hsieh (2013), menemukan bahwa ada penurunan yang signifikan tingkat ansietas, tingkat kenyamanan setelah dilakukan pijat punggung pada pasien dengan congestive heart failure $(\mathrm{F}[2,61]=4,31, \mathrm{p}=0,02)$. Secara fisologis juga dikatakan dengan pijat punggung merangsang keluarnya hormon endorfin (Noonan, 2006) dari lokasi nosiseptor, terminal saraf kornu dorsalis medula spinalis (Potter \& Perry, 2013). Tekanan darah sistolik sebelum intervensi pada kelompok intervensi dan kelompok kontrol memperlihatkan bahwa kelompok intervensi $(153,53 \mathrm{mmHg})$ dan kelompok kontrol $(141,80 \mathrm{mmHg})$ mempunyai tekanan darah sistolik yang relatif sama tinggi dengan kelompok kontrol sebelum diberikan pijat punggung $(\mathrm{p}=0,112)$.

Penelitian terdahulu cortisol responses to mental stress and the progression of coronary artery calcification in healthy men and women, membuktikan bahwa ada hubungan yang signifikan antara peningkatan kortisol sebagai reaksi dari peningkatan stres dan kalsifikasi arteri koronaria yang pada gilirannya memungkinkan terjadinya stres psikososial yang dapat memengaruhi penyakit jantung koroner (Hamer, Endrighi, Venraju, Lahiri \& Steptoe, 2012). Penelitian lain menemukan bahwa stres mental dapat berpengaruh pada tekanan darah dan denyut nadi (Hjortskov, et al., 2004).

Pengukuran tekanan darah sistolik kelompok intervensi terlihat lebih tinggi dibandingkan dengan tekanan darah sistolik kelompok kontrol sebelum pijat punggung, asumsi ini bila dikaitkan dengan konsep model dari Spielberger tentang State and Trait Anxiety (STAI) menjelaskan ansietas, proses mengalami ansietas sebagai akibat dari interaksi stimulus internal dan eksternal stimulus, faktor kognitif, dan mekanisme pertahanan tubuh. Model ini menjelaskan bahwa anxious state ditandai dengan respon fisiologis dan pikiran merasa terasing, akibat stresor eksternal atau penyebab internal.

Tekanan darah sistolik sesudah intervensi pada kelompok intervensi dan kelompok kontrol memperlihatkan bahwa kelompok intervensi $(141,13 \mathrm{mmHg})$ dan kelompok kontrol $(142,67$ $\mathrm{mmHg}$ ) mempunyai tekanan darah sistolik yang relatif tetap sama tinggi dengan kelompok kontrol sebelum diberikan pijat punggung $(\mathrm{p}=0,826)$. Walaupun tekanan darah sistolik kelompok intervensi terlihat penurunan menjadi 141,13 $\mathrm{mmHg}$ dari $153,53 \mathrm{mmHg}$, yang secara statistik dinilai tidak signifikan sedangkan pada penelitian terdahulu tanda vital dapat turun setelah pijat punggung (Liebert, 2012) sementara menurut Hamer, et al., (2012) tekanan darah relatif menetap karena ada kalsifikasi arteri koronaria karena penumpukan kortisol, dan pada penelitian lain dikatakan bahwa stres mental dapat berpengaruh pada tekanan darah dan denyut nadi (Hjortskov, et al., 2004).

Tekanan darah diastolik sebelum intervensi pada kelompok intervensi dan kelompok kontrol memperlihatkan bahwa kelompok intervensi $(76,60 \mathrm{mmHg})$ dan kelompok kontrol $(80,73$ $\mathrm{mmHg}$ ) mempunyai tekanan darah diastolik yang relatif sama tinggi dengan kelompok kontrol sebelum diberikan pijat punggung $(\mathrm{p}=0,352)$. Menurut Hamer, et al., (2012) ini diakibatkan karena kalsifikasi arteri koroner yang disebabkan penumpukan kortisol, dan stres mental (Hjortskov, et al., 2004). Hasil analisis tekanan darah diastole 
sesudah intervensi pada kelompok intervensi dan kelompok kontrol memperlihatkan bahwa kelompok intervensi $(68,80 \mathrm{mmHg})$ dan kelompok kontrol $(78,87 \mathrm{mmHg})$ mempunyai tekanan darah diastolik yang relatif menurun dengan kelompok kontrol sebelum diberikan pijat punggung $(\mathrm{p}=0,016)$, tekanan darah diastolik kelompok intervensi terlihat penurunan menjadi $68,80 \mathrm{mmHg}$ dari $76,60 \mathrm{mmHg}$.

Menurut Olney (2002) dalam penelitiannya back massage long term effect and dosage determination for person with pre hypertension and hypertension, dikatakan bahwa diperlukan intervensi berulang dan dalam waktu lama untuk menurunkan tekanan darah pasien dengan tekanan darah yang tinggi atau pasien pre hipertensi. Pada penelitian ini tekanan darah hanya diukur sekali setelah intervensi dengan pijat punggung hanya sekali, cukup bermakna untuk menurunkan tekanan darah diastolik.

Denyut nadi sebelum intervensi pada kelompok intervensi dan kelompok kontrol memperlihatkan bahwa kelompok intervensi (76,00 kali/menit) dan kelompok kontrol (79,07 kali/menit) mempunyai denyut nadi yang relatif sama tinggi dengan kelompok kontrol sebelum diberikan pijat punggung $(\mathrm{p}=0,444)$. Hasil analisis denyut nadi sesudah intervensi pada kelompok intervensi dan kelompok kontrol memperlihatkan bahwa denyut nadi kelompok intervensi (65 kali/ menit) menjadi menurun secara signifikan dibandingkan dengan denyut nadi kelompok kontrol (81,47 kali/menit dari jumlah 79,07 kali/menit) meningkat dan tidak diintervensi dengan pijat punggung $(\mathrm{p}=0,0001)$ walaupun pada awalnya kedua kelompok mempunyai denyut nadi yang relatif sama tinggi sebelum intervensi.

Respirasi sebelum intervensi pada kelompok intervensi dan kelompok kontrol memperlihatkan bahwa kelompok intervensi $(20,13 \mathrm{kali} /$ menit $)$ dan kelompok kontrol (19,87 kali/menit) mempunyai respirasi yang relatif sama tinggi dengan kelompok kontrol sebelum diberikan pijat punggung $(\mathrm{p}=0,733)$. Penelitian terdahulu membuktikan bahwa respons dari hormon stres terjadi pada stres fisiologis dan stres psikologis. Terjadi juga interaksi yang signifikan dalam penelitian tersebut antara respons kardiorespirasi dengan denyut jantung, ventilasi, dan respirasi yang memperlihatkan peningkatan adanya kondisi stres fisiologis dan psikologis (Webb, et al., 2008). Stres menunggu tindakan coronary angiography merupakan salah satu stressor yang dapat mengakibatkan peningkatan denyut nadi, pernafasan, aktivitas saluran cerna, dan liver melepaskan glukosa untuk energi, sebagai respon dari stimulus stressor (McLeod, 2010)

Respirasi sesudah intervensi pada kelompok intervensi dan kelompok kontrol memperlihatkan bahwa respirasi kelompok intervensi $(18,47$ $\mathrm{kali} /$ menit) menjadi menurun secara signifikan dibandingkan dengan respirasi kelompok kontrol $(19,87 \mathrm{kali} /$ menit) tetap, tidak diintervensi dengan pijat punggung $(\mathrm{p}=0,005)$, walaupun pada awalnya kedua kelompok mempunyai respirasi yang relatif sama tinggi sebelum intervensi. Stres menunggu tindakan coronary angiography merupakan salah satu stressor yang dapat mengakibatkan peningkatan denyut nadi, pernafasan, aktivitas saluran cerna, dan liver melepaskan glukosa untuk energi, sebagai respon dari stimulus stresor (McLeod, 2010), dengan pijat punggung respon fisiologis ini dapat dibantu diadaptasi dengan lebih baik (Wentworth, et al., 2009).

Suhu sebelum intervensi pada kelompok intervensi dan kelompok kontrol memperlihatkan bahwa kelompok intervensi $\left(36,51^{\circ} \mathrm{C}\right)$ dan kelompok kontrol $\left(36,67^{\circ} \mathrm{C}\right)$ mempunyai suhu yang relatif sama tinggi sebelum dilakukan intervensi $(\mathrm{p}=$ 0,324). Menurut mekanisme fisiologi tubuh suhu dipengaruhi oleh lingkungan, bila lingkungan atau ruangan panas tubuh tidak mampu mengatur suhu tubuh dengan mekanisme heat loss, sehingga suhu tubuh akan naik, sebaliknya lingkungan yang dingin berakibat extensive radiant dan panas hilang karena konduksi (Potter \& Perry, 2013). Penelitian ini dilakukan pada ruangan dengan suhu $16{ }^{\circ} \mathrm{C}$, hal ini yang menyebabkan suhu tubuh pasien tetap pada kondisi normal dan cenderung kurang dari $37{ }^{\circ} \mathrm{C}$. Hasil analisis 
suhu sesudah intervensi pada kelompok intervensi dan kelompok kontrol memperlihatkan bahwa kelompok intervensi $\left(36,33{ }^{\circ} \mathrm{C}\right)$ dan kelompok kontrol $\left(36,33{ }^{\circ} \mathrm{C}\right)$ mempunyai suhu yang relatif tetap sama tinggi dengan kelompok kontrol sesudah diberikan pijat punggung $(\mathrm{p}=0,052)$, suhu kelompok intervensi setelah pijat punggung terlihat ada penurunan dari $36,51{ }^{\circ} \mathrm{C}$ menjadi $36,33{ }^{\circ} \mathrm{C}$. Penelitian terdahulu yang dilakukan pada the effect of back-massage on the vital signs and anxiety level of elderly staying in a rest home, menemukan bahwa kecuali suhu tubuh, ada penurunan secara signifikan pada tanda-tanda vital segera setelah pijat punggung, diukur 15 menit, dan 30 menit kemudian, juga pengukuran hasil selama 3 hari berturut. Penelitian dilakukan pada responden dengan rata-rata usia 62-85 tahun (Cinar, Eser, \& Ismet, 2009). Pada penelitian ini sedikit berbeda dengan penelitian tersebut yaitu pengukuran hanya dilakukan satu kali segera setelah pemberian pijat punggung dan responden yang berusia antara 43-73 tahun. Penelitian ini dilakukan pada ruangan dengan suhu $16^{\circ} \mathrm{C}$, pengaruh lingkungan ini yang menyebabkan suhu tubuh pasien tetap pada kondisi normal dan cenderung kurang dari $37^{\circ} \mathrm{C}$.

Hasil analisis statistik pada hubungan tingkat kecemasan dan tingkat kenyamanan setelah pijat punggung menjelaskan bahwa semakin tinggi tingkat kecemasan akan semakin rendah tingkat kenyamanan $(p=0,001 ; \alpha=0,05)$. Penelitian lain membuktikan bahwa pasien sebagai makhluk sosial, mendapatkan rasa nyaman dari dukungan sosial karena membutuhkannya untuk mengurangi stres, dapat percaya kepada orang lain, aman untuk berhubungan dengan orang lain serta mempunyai jaringan sosial yang lebih luas (Kaniasty $\&$ Norris, 2000).

\section{Kesimpulan}

Gambaran umum karakteristik responden yang mengikuti penelitian ini yaitu usia rata-rata; persentase jenis kelamin laki-laki dan perempuan; persentase pendidikan SLTP, SLTA, dan PT; jenis pekerjaan responden yang terdiri dari pega- wai negeri sipil, swasta, dan lain-lain termasuk pensiunan. Ada hubungan tingkat kecemasan dan kenyamanan sesudah pijat punggung sebelum tindakan coronary angiography. Ada pengaruh pijat punggung terhadap tingkat kecemasan pasien sebelum tindakan coronary angiography setelah dikontrol dengan karakteristik pasien. Ada pengaruh pijat punggung terhadap tingkat kenyamanan pasien sebelum tindakan coronary angiography setelah dikontrol dengan karakteristik pasien. Ada pengaruh pijat punggung terhadap tekanan darah diastolik, frekuensi nadi dan respirasi, dan suhu pasien sebelum tindakan angiografi koroner setelah dikontrol dengan karakteristik pasien. Tidak ada pengaruh pijat punggung terhadap tekanan darah sistol sesudah intervensi sebelum tindakan coronary angiography.

Saran atau rekomendasi selanjutnya untuk melakukan penelitian tentang pengaruh pijat punggung terhadap tingkat kecemasan dan kenyamanan dengan cara: mengikutsertakan faktor konfonding usia, jenis kelamin, pendidikan, dan pekerjaan dalam penelitian dengan menganalisis pengaruh terhadap tingkat kecemasan, tingkat kenyamanan, TD, nadi, respirasi, dan suhu. Melakukan analisis data dalam bentuk kategorik. Melakukan penelitian tentang teknik pijat punggung dengan tekanan berbeda pada punggung pasien. Melakukan evidence based practice untuk menempatkan pijat punggung sebagai bagian dari standar prosedur operasional tindakan angiography pasien dewasa dan pediatrik. (TG, HH, AR)

\section{Referensi}

Black, M.J., \& Hawks. J.H. (2009) Medical surgical nursing: Clinical management for positive outcome (8th Ed.). St Louis Missouri: WB Saunders

Chen, W., Liu, G.J., Yeh, S.H., Chiang, M.C., Fu, M.Y., \& Hsieh, Y.K. (2012). Effect of back massage intervention. Diperoleh dari http:// www.ncbi.nlm.nih.gov/pubmed/23186129.

Cinar, S., Eser, I., \& Khorshid, L. (2009). The 
effects of back massage on the vital signs and anxiety level of elderly staying in a rest home. Diperoleh dari http://www.hacette pehemsirelikdergisi.org/pdf/pdf_HHD_76.pdf.

Dharma, K.K. (2011). Metodologi penelitian keperawatan, panduan melaksanakan dan menerapkan hasil penelitian. Jakarta: TIM

Dowd, T., Kolcaba, K., Steiner, R., \& Fashinpaur, D. (2007). Verbal rating scale questionnaire comparision of healing touch, coaching, and a combined intervention on comfort and stress in younger college students. Holistic Nursing Practice, 21(4), 194-202.

Eran, A., Erdmann, E., \& Er, F. (2010). Informed consent prior to coronary angiography in a real world scenario: what do patients remember? Diperoleh dari http://journals. plos.org/plosone/article?id=10.1371/journa 1.pone. 0015164 .

Hinz, A., Kittel, J., Karoff, M., \& Daig, I. (2011). Anxiety and depression in cardiac patients: Age differences and comparisons with the general population. Psychopathology, 44(5), 289-295. Doi: 10.1159/000322796.

Hajbaghery, M.A., Abasi, A., Beheshtabad, R.R, \& Fini, I.A. (2012). The Effects of Massage Therapy by the Patient's Relative on Vital Signs of Males Admitted in Critical Care Unit. Nursing and Midwifery Studies, 1(1), 16-21. Doi:10.5812/nms.7903.

Hamer, M., Endrighi, R., Venuraju, S. M., Lahiri, A., \& Steptoe, A. (2012). Cortisol responses to mental stress and the progression of coronary artery calcification in healthy men and women. Diperoleh dari http://www.ncbi.nlm.nih.gov/pubmed/22 328931.

Kugler, M. (2009). Waiting for diagnosis: The time you spend waiting for a diagnosis can be emotional. Diperoleh dari http://rarediseases. about.com.

Hjortskov, N., Rissén, D., Blangsted, A. K., Fallentin, N., Lundberg, U., \& Søgaard, K. (2004). The Effect of Mental stress on Heart Rate Variability and Blood Pressure during Computer Work. European journal of applied physiology, 92(1-2), 84-9. Doi: 10.1007/s00421-004-1055-z.

Kari, A.R. (2009). Exploration of The Quality of Three Measures for Assessing State Anxiety in Hospitalized cardiac. Diperoleh dari http://search.proquest.com/docview/30498 7249/fulltextPDF/13CFC24637D527AD50 $\mathrm{F} / 8$ ? accountid $=17242$.

Kaniasty, K., \& Norris, F.H. (2000). Helpseeking comfort and Receiving Social Support: the role of ethnicity and context of need. American journal of community psychology, 28(4), 545-581.

Kolcaba, K. (2010). An introduction to comfort theory. Diperoleh dari http://www.thecomfort line.com/.

McLeod, S. (2010). What is the stress response. Diperoleh dari http://www.simplypsychology. org/stress-biology.html.

Olney, C.M. (2007). Back massage long term effects and dosage determination for persons with pre-hypertension and hypertension. Diperoleh dari http://scholar commons.usf.edu/cgi/viewcontent.cgi?arti cle $=3306 \&$ context $=$ etd.

Liebert, M.A. (2013). Effect of massage intervention on anxiety, comfort and physiological respons in patient congestive heart failure. Journal of Alternative and Complementary Medicine, 19(5), 464-4 70.

McNamara, M.E., Burnham, D.C., Smith C., \& Carroll, D.L. (2003). The effects of Masase massage before diagnostic cardiac catheterization. Diperoleh dari http://www.ncbi. nlm.nih.gov/pubmed/12564351.

Noonan.T. (2006). Effect of massage therapy techniques on the autonomic nervous system (ANS), endocrine and the other body systems. Diperoleh dari http://www.tim noonan.com.au/maspap98.htm. 
Potter, P.A., \& Perry, A.G. (2013) Fundamentals of nursing (8th Ed.). St Louis, Missouri: Elsevier Mosby.

Steinberg, T., Roseman, M., Kasymjanova, G., Dobson, S., Lajeunesse, L., Dajczman, E., Kreisman, H., MacDonald, N., Agulnik, J., Cohen, V., Rosberger, Z., Chasen, M., Small, D. (2009). Prevalence of emotional distress in newly diagnosed lung cancer patients. Supportive care in cancer: Official journal of the multinational association of supportive care in cancer, 17(12), 1493-1497. Doi: 10.1007/s00520009-0614-6.

Sugiono, J. (2010). Metoda Pendekatan Kuantitatif. Bandung: Alfabeta.
Webb, H.E., Weldy, M.L., Fabianke-Kadue, E.C., Orndorff, G.R., Kamimori, G.H., \& Acevedo, E.O. (2008). Psychological stress during exercise: cardiorespiratory and hormonal responses. European journal of applied physiology, 104(6), 973-981. Doi: 10.1007/s00421-008-0852-1.

Wentworth, L.J., Briese, L.J., Timimi, F.K., Sanvick, C.L., Bartel, D.C., Cutshall, S.M., Tilbury, R.T., Lennon, R., Bauer, B.A. (2009). Massage therapy reduces tension, anxiety, and pain in patients awaiting invasive cardiovascular procedures. Progress in cardiovascular nursing, 24(4), 155-161. Doi: 10.1111/j.1751-7117.2009.00054.x. 